\title{
A technique for fabricating abutment replica with hot melt adhesive material to minimize residual cement in implant restoration: a case report
}

\author{
Chi-Won Seo, A-Reum Han, Jae-Min Seo, Jung-Jin Lee* \\ Department of Prosthodontics and Institute of Oral Bio-Science, School of Dentistry, Chonbuk National University, Jeonju, \\ Republic of Korea
}

\begin{abstract}
Removal of excess cement is important to prevent biological complication in cementation of implant restoration with subgingival margin. It can be difficult to completely remove excess cement. Several techniques have been introduced to minimize excess cement using abutment replica. In this case report, a simple method for making abutment replica with hot melt adhesive material in dental office was described. This technique is simple and effective because it can be used for pre-fabricated or custom abutment without additional laboratory procedure. In addition, it can minimize excess cement after cementation of implant restoration. (J Dent Rehabil Appl Sci 2016;32(3):240-5)
\end{abstract}

Key words: implant; cement; periimplatitis, subgingival margin

\section{Introduction}

Cement retained implant restorations have several advantages over screw retained ones. First, it is easier to achieve passive fit. Second, they are more aesthetic and easier to apply occlusal force in longitudinal direction. ${ }^{1}$ It can be difficult to remove residual cement underneath the subgingival margin of restoration. However, excess cement causing periimplantitis should be removed.

Several cementation techniques using abutment replica have been introduced to remove excess cement, making it possible to properly retain restoration while minimizing residual cement. ${ }^{2}$ Materials such as polyvinyl siloxane impression, bite material,

*Correspondence to: Jung-Jin Lee

Fellowship, Department of Prosthodontics, School of Dentistry and Institute of Oral Bio-Science, Chonbuk National University, 567, Baekje-daero, Deokjin-gu, Jeonju, 54896, Republic of Korea

Tel: +82-63-250-2050, Fax: +82-63-250-2218, E-mail: wjdwls04@gmail.com Received: August 8, 2016/Last Revision: August 23, 2016/Accepted: August 25, 2016 and acrylic resin have been used. ${ }^{3-5}$ Technique for fabricating replica with resin block using computer aided design/computer aided manufacturing (CAD/ CAM) is also possible. ${ }^{6}$ However, these techniques are complicated. They require additional cost and equipment.

In this case report, a procedure to simply and quickly fabricate abutment replica at chairside is described. ${ }^{7}$ It uses hot melt adhesive material (HMA), a thermoplastic material consisting of ethylene vinyl acetate copolymer, wax, resins, pigment, and other components. ${ }^{8}$ Dentist can make a flexible model to fabricate temporary restorations using an electric glue gun. ${ }^{9}$ Because HMA has good flow, good strength, and good flexibility, it can be applied to narrow areas

CopyrightC 2016 The Korean Academy of Stomatognathic Function and Occlusion. (c) It is identical to Creative Commons Non-Commercial License. 
such as the incisal edge without causing fracture.

\section{Case Report}

A 22-year-old male patient with discoloration and gingival recession of the maxillary right central incisor received endodontic treatment due to injury nine years ago. He presented at the Department of Prosthodontics, Chonbuk National University Hospital. Maxillary right central incisor showed grade II mobility (according to the Miller classification). The $5 \mathrm{~mm}$ of periodontal pocket depth was measured at distal surface. Half of his palatal surface of teeth was destroyed (Fig. 1). Cone-beam computed tomography (CBCT) was taken to evaluate bone height and width. Considering the age and sex of the patient, the tooth with poor prognosis was extracted and implant placement was determined.

After 3 months for tooth extraction, guided bone regeneration (GBR) was performed with xenograft material (Bio-Oss ${ }^{\circledR}$, Geistlich, Wilhusen, Switzerland), titanium mesh (T4 Neo tatinium mesh, Neobiotec, Seoul, Korea), and collagen membrane (Genoss Co., Ltd., Suwon, Korea) to obtain wide alveolar bone. At 7 months post GBR surgery, implant fixture (Superline $3.6 \times 12 \mathrm{~mm}$, Dentium Co., Seoul, Korea) was placed. Good initial stability was observed. After 6 months, the second surgery was carried out. Since good osseointegration was observed, provisional restoration was connected with $20 \mathrm{Ncm}$. Interdental papilla was stably maintained for 3 months (Fig. 2). For duplicating the emergence profile of provisional restoration, custom impression coping was fabricated with pick-up type impression coping (DPU4011HL, Dentium Co., Seoul, Korea). Final impression was taken with polyvinyl siloxane (Aquasil XLV/Monophase, Dentsply Caulk, Milford, USA). Working cast was fabricated with type IV dental stone (Fuijirock EP, GC, Tokyo, Japan). Zirconia custom abutment with titanium insert (RaphaBio, Seoul, Korea) and veneered zirconia restoration was fabricated with CAD/CAM.
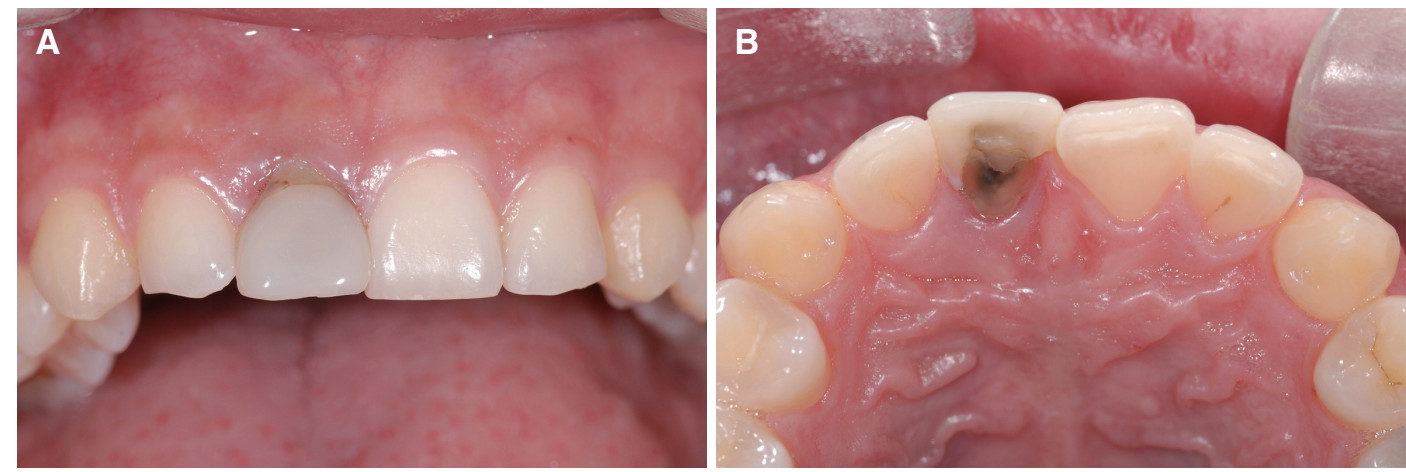

Fig. 1. Initial examination. (A) Right maxillary central incisor showing discoloration, (B) Destroyed palatal surface.

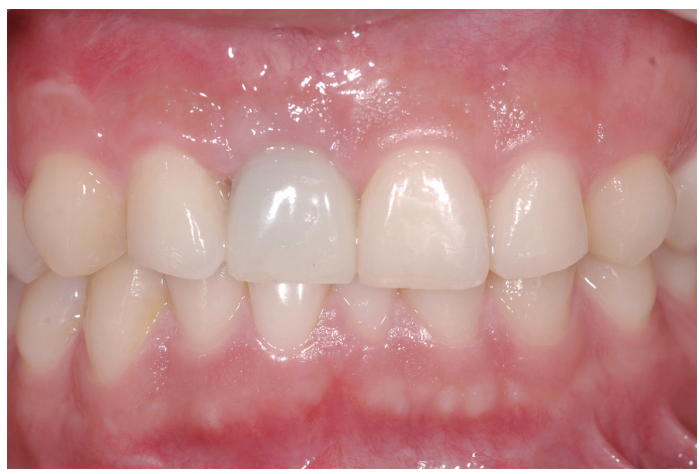

Fig. 2. Soft tissue around implant was well maintained for 3 months after connecting provision restoration. 
For fabricating the abutment replica with HMA, a thin layer of petroleum jelly (Vaseline, Unilever, London, UK) was applied to the inner surface of the zirconia crown using a microbrush (Microbrush International, Grafton, USA). The HMA (GS1085, Okong, Incheon, Korea) was filled inside of the restoration using an electronic glue gun (G250, Okong, Incheon, Korea). Dowel pin (Twin pin, World D\&D Co., Seoul, Korea) was placed into the HMA and the replica was immersed into water to determine the space for cement after shrinkage (Fig. 3A). If any defect was found on the surface of HMA abutment replica in this stage, a small amount of HMA could be used re-fill the restoration and re-seat the replica. After HMA was cooled, any excess HMA present in the margin of the abutment replica was trimmed with a knife (Fig. 3B). After that, the custom abutment was connected to the implant for $30 \mathrm{Ncm}$ with electric torque wrench (iSD 900, NSK Inc., Kanuma, Japan). The occlusal contact of the restoration was adjusted using a conventional procedure. After 10 minutes, screw was re-tighten ${ }^{10}$ and screw hole was filled with cotton pellet and composite resin (Filtek z250, 3M EPSE AG, Seefeld, Germany). The inner surface of the restoration was cleaned with airborne particle abrasion. Resin cement (RelyX ultimate clicker, 3M EPSE AG) was applied along the margin with minimum amount. ${ }^{11}$ The HMA abutment replica was seated to the restoration with a light pressure (Fig. 4A). Any excess cement around the margin was wiped and the abutment replica was immediately pulled off. After confirming that the cement has been evenly applied to the inner surface of the restoration (Fig. 4B), the restoration was seated on the abutment within the oral cavity. Any cement flowing outside was removed after the cement was hardened (Fig. 5).
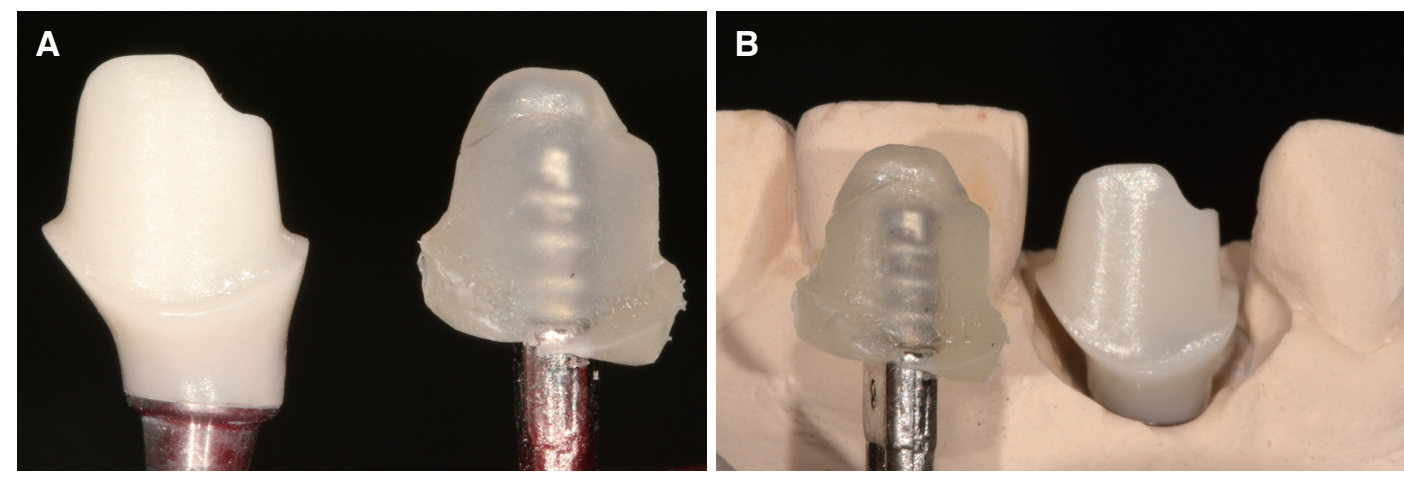

Fig. 3. (A) Fill the restoration with melted HMA and place the dowel pin, (B) Zirconia custom abutment (right) and hot melt adhesive material replica (left).
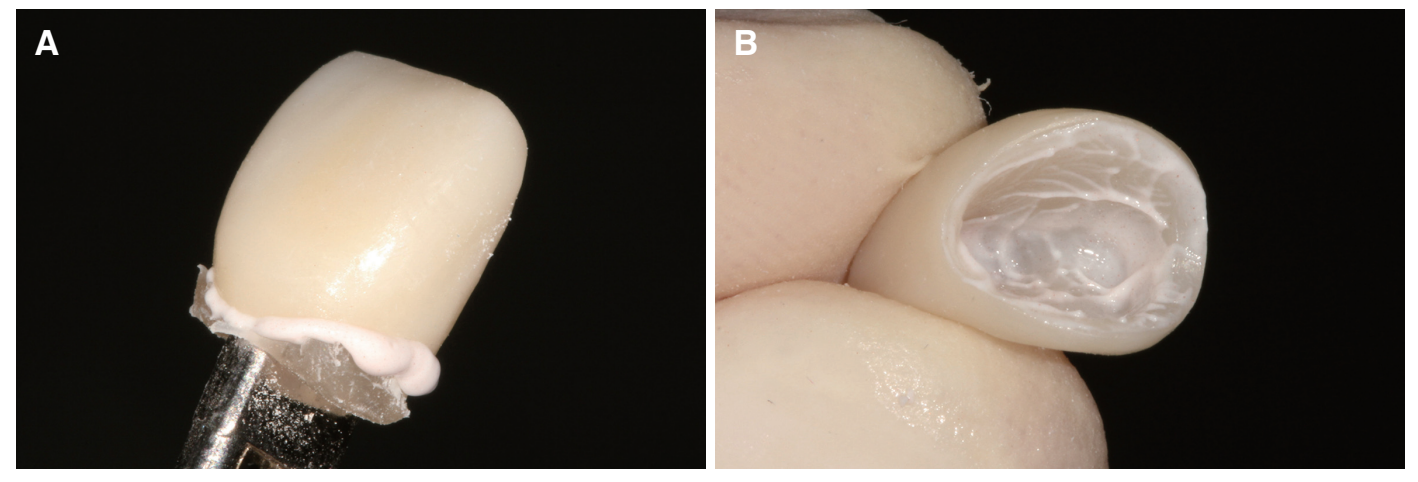

Fig. 4. (A) Apply cement, seat abutment replica, and wipe off excess cement, (B) Remove replica from seating and confirm that the cement has coated the inside. 

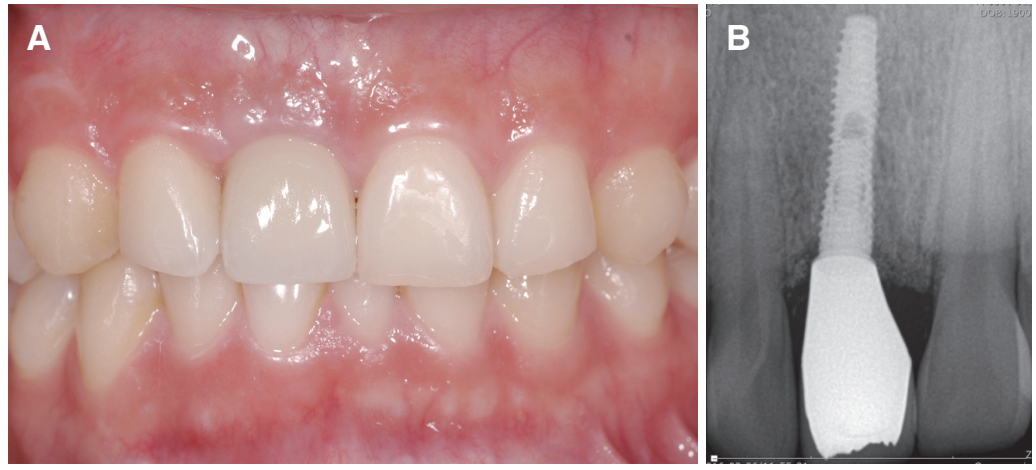

Fig. 5. (A) Zirconia crown was cemented with resin cement, (B) Periapcal radiograph. No cement remaining was observed.

Patient instruction for cleaning was conducted. At re-call check appointments after 1, 3, 6 months, no exudation or pus discharge was observed. The patient was satisfied with the esthetics and function of the prostheses.

\section{Discussion}

Restoration with subgingival margin is widely used for aesthetics in anterior area. Since the emergence profile of anterior implant prostheses is rapidly widened, it is highly likely for cement to retain between the abutment and gingival. ${ }^{12}$ However, complete removal of excess cement is difficult. Undetected cement might cause periimplantitis. The risk of undetected excess cement is well known. ${ }^{13}$ In the process of removing cement with a plastic or titanium instrument, scratch can occur on the implant abutment, which can accelerate plaque and bacterial deposition. ${ }^{14}$ Even though cement with water-solubility or radiopacity is used, it is difficult to find cement that is thinly remained on the surface of the abutment or gingiva. ${ }^{15}$ Factors that can determine the amount of excess cement include the amount of cement used, viscosity and flowability of the cement, margin location, ability to remove unset cement, abutment material, and abutment shape. ${ }^{15}$

To minimize excess cement and obtain proper retention, using abutment replica is effective. ${ }^{2}$ Abut- ment replica can be fabricated by duplicating the abutment with resin or polyvinyl siloxane material. This case report introduced a technique to fabricate abutment replica with HMA at chairside. As excess cement can be removed before seating the restoration to abutment, the remained cement can be minimized after cementation. However, this technique has a limitation. Because even shrinkage of HMA cannot be controlled, uniform and precious space for cement cannot be obtained. Nonetheless, this simple technique can be used for cementation of implant restoration with subgingival margin to minimize excess cement. Since it needs no additional laboratory procedure, it is quick and effective.

\section{Conclusion}

In this case report, the abutment replica was simply fabricated with hot melt adhesive material to minimize the excess cement of anterior implant prosthesis in dental office. Since the excess cement is harmful to the peri-implant tissue, the biologic complication can be reduced for using this technique.

\section{Acknowledgments}

The authors thank the dental laboratory of Chonbuk National University Hospital, Byeong-Yong Ko, for technical assistance. 


\section{ORCID}

Chi-Won Seo http://orcid.org/0000-0003-0745-8199

A-Reum Han http://orcid.org/0000-0002-9432-7244

Jae-Min Seo http://orcid.org/0000-0001-5095-4046

Jung-Jin Lee http://orcid.org/0000-0002-7381-5230

\section{References}

1. Hebel KS, Gajjar RC. Cement-retained versus screw-retained implant restorations: achieving optimal occlusion and esthetics in implant dentistry. J Prosthet Dent 1997;77:28-35.

2. Liang T, Hu X, Zhu L, Pan X, Zhou Y, Liu J. Comparative in vitro study of cementing techniques for implant-supported restorations. J Prosthet Dent 2016;116:59-66.

3. Chee WW, Duncan J, Afshar M, Moshaverinia A. Evaluation of the amount of excess cement around the margins of cement-retained dental implant restorations: the effect of the cement application method. J Prosthet Dent 2013;109:216-21.

4. Wadhwani C, Piñeyro A. Technique for controlling the cement for an implant crown. J Prosthet Dent 2009;102:57-8.

5. Galván G, Kois JC, Chaiyabutr Y, Kois D. Cemented implant restoration: a technique for minimizing adverse biologic consequences. J Prosthet Dent 2015;114:482-5.

6. Lee JH, Park IS, Sohn DS. A digital approach to fabricating an abutment replica to control cement volume in a cement-retained implant prosthesis. J Prosthet Dent 2016;116:25-8.

7. Rayyan MM, Makarem HA. A modified technique for preventing excess cement around implant sup- ported restoration margins. J Prosthet Dent 2016 Jul 23. doi:10.1016/j.prosdent.2016.04.007. [Epub ahead of print]

8. Li W, Bouzidi L, Narine SS. Current research and development status and prospect of hot-melt adhesives: a review. Ind Eng Chem Res 2008;47:752432.

9. Dimashkieh MR, Rayyan MR. Chairside technique for expediting indirect interim restorations. J Prosthet Dent 2016;115:510-1.

10. Siamos G, Winkler S, Boberick KG. Relationship between implant preload and screw loosening on implant-supported prostheses. J Oral Implantol 2002;28:67-73.

11. Wadhwani C, Goodwin S. Chung KH. Cementing an implant crown: a novel measurement system using computational fluid dynamics approach. Clin Implant Dent Relat Res 2016;18:97-106.

12. Hermann JS, Buser D, Schenk RK, Schoolfield JD, Cochran DL. Biologic width around one- and twopiece titanium implants. Clin Oral Implants Res 2001;12:559-71.

13. Gapski R, Neugeboren N, Pomeranz AZ, Reissner MW. Endosseous implant failure influenced by crown cementation: a clinical case report. Int J Oral Maxillofac Implants 2008;23:943-6.

14. Pauletto N, Lahiffe BJ, Walton JN. Complications associated with excess cement around crowns on osseointegrated implants: a clinical report. Int J Oral Maxillofac Implants 1999;14:865-8.

15. Wadhwani C, Rapoport D, La Rosa S, Hess T, Kretschmar S. Radiographic detection and characteristic patterns of residual excess cement associated with cement-retained implant restorations: a clinical report. J Prosthet Dent 2012;107:151-7. 


\section{임플란트 보철 합착 시 잔여 시멘트 최소화를 위해 열가소성 접착제를 이용한 복제 지대주 제작 방법: 증례보고}

서치원, 한아름, 서재민, 이정진*

전북대학교 치의학전문대학원 치과보철학교실 및 구강생체과학연구소

치은 연하 변연을 갖는 임플란트 수복물 장착시 잔여 합착제의 제거는 임플란트 생물학적 합병증을 예방하기 위해 매우 중요하다. 치은 연하 잔여 합착제를 최소화하기 위해 인상용 실리콘이나 자가중합형 레진을 이용하여 복제 지대주를 제 작하는 여러 방법이 소개되었다. 본 증례에서는 열가소성 접착제(hot melt adhesive material)를 이용하여 복제 임플란트 지대주(abutment replica)제작하는 방법을 소개하고자 한다. 이 방법은 간단하고 부가적인 기공과정이 필요 없어 진료실 에서 쉽게 이용할 수 있어 이에 보고하는 바이다.

(구강회복응용과학지 2016;32(3):240-5)

주요어: 임플란트; 합착제; 임플란트 주위염; 치은연하 변연 